\title{
Światu nie mamy czego zazdrościć* - o studenckich lekcjach dobrego sąsiedztwa i (gość)inności na podstawie najnowszych reportaży Implikacje dydaktyczne
}

\author{
Nothing to Envy \\ On Classes for University Students on Good Neighbourhood \\ and Host(ility)/Otherness Based on the Latest Reportages \\ Implications for Teaching
}

Summary: The article describes the semester classes conducted at the Faculty of Philology of the University of Silesia based on reportage texts on the hardship of refugees. It consists essentially of three parts, which answer the questions: why the documentary genre should become more present in school?, why the topic of refugees and economic migrants should be made the subject of students' discussions during Polish language classes? and how to introduce reading about good neighbourhood and hospitality? In this study, I propose non-fiction texts about the greatest migration crisis after the Second World War, which can be successfully implemented in the Polish language classes.

Key words: refugees, Polish language classes, reportage, Polish language students, Polish philology

* B. Demick: Światu nie mamy czego zazdrościć. Zwyczajne losy mieszkańców Korei Pótnocnej. Tłum. A. Nowakowska. Wołowiec 2011. 


\section{O reportażu}

Wojciech Tochman w wywiadzie na temat kondycji polskiego reportażu opublikowanym na stronach portalu Culture.pl podkreśla, że ludzie czytają reportaże znacznie chętniej niż fikcję. Tendencję tę powinniśmy wspierać w czasach, kiedy już nie czytamy prawie niczego — dodaje ${ }^{1}$. Ponadto zauważa niepokojącą skłonność polskich mediów: w coraz większym stopniu stają się one prowincjonalne, interesują się głównie własnym ,grajdołkiem”. Inny z sąsiedniej wsi, z sąsiedniego kraju jest daleki i zasadniczo nas nie obchodzi, dopóki nie staje na naszej drodze i nam nie zagraża. W polskim reportażu z ostatnich lat Tochman doświadczył zjawiska zupełnie odwrotnego. Tak o nim mówi:

[...] Prawie wszyscy pisaliśmy o Polsce przez wiele lat. Wydaliśmy o tym książki. [...] Nasz kraj przeze mnie widziany i opisany nie jest przyjemny, a raczej pełny kompleksów, hipokryzji, strachu przed obcym i innym. Czy coś się od tego czasu zmieniło? Czy jesteśmy inni? Nie sądzę. Więc po co się powtarzać, mielić w kółko to samo? Wolę do pracy wyjechać. Podobnie chyba koledzy. Z naszego zawodowego punktu widzenia świat poza Polską wydaje się ciekawszy. Może powinniśmy się cieszyć, że żyjemy w takim nie do końca przyjemnym, ale jednak nudnym kraju. Bo tam, gdzie dzieje się coś ważnego, zwykle nie jest spokojnie, tam ludzie cierpią ${ }^{2}$.

Nie dziwi zupełnie, że polscy autorzy non-fiction opowiadają o dalekim świecie, o ludziach i kulturach nam nieznanych lub słabo znanych: Mariusz Szczygieł, Jacek Hugo-Bader, Mariusz Wilk piszą o naszych sąsiadach, Wojciech Jagielski sporo miejsca poświęca Afryce, Witold Szabłowski opisuje Turcję, Andrzej Muszyński przybliża odbiorcy Azję i Amerykę Południową, Katarzyna Boni podjęła temat kataklizmu tsunami w Japonii, a Tochman i Małgorzata Szejnert piszą o Filipinach i o odległym Zanzibarze. W krajach tych dzieje się więcej, ludzie cierpią, a ich historie są dla czytelników nie tylko źródłem poznania, ale także emocji. Nasza psychika odbiorcza skonstruowana jest tak, że ciągnie nas tam, gdzie jest niespokojnie, gdzie często przelewa się krew $^{3}$. Literatura non-fiction pozwala nam ten „głód” wrażeń zaspokajać, ale

${ }^{1}$ Zob. Raport o stanie czytelnictwa TNS Polska dla Biblioteki Narodowej, według którego w 2015 roku ani jednej książki nie przeczytało 63\% Polaków, a w 2014 roku - 58\%. Widać zatem, że w ciągu 12 miesięcy poziom czytelnictwa spadł o 5\%.

${ }^{2}$ Wojciech Tochman o polskim reportażu - wywiad. http://culture.pl/pl/artykul/wojciech-tochman-o-polskim-reportazu-wywiad [data dostępu: 18.02.2017].

${ }^{3}$ Zob. http://katowice.wyborcza.pl/katowice/1,35055,19784678,ryszard-koziolek-houelle becq-ukradl-mysl-z-mojej-glowy.html [data dostępu: 18.02.2017]. 
też oglądać, analizować i interpretować teksty o dramatach ludzkich w sposób bezpieczny.

Zapewne reportażyści piszący o Polsce mają dość ograniczoną perspektywę, a opis własnego kraju nie należy do najłatwiejszych. Trafną syntezę Tochmana potwierdzają najnowsze faktograficzne teksty Marcina Kąckiego o zróżnicowanym historycznie mieście pogranicza $\mathrm{z}$ wielokulturową przeszłością i ksenofobiczną teraźniejszością — o Białymstoku ${ }^{4}$ — oraz o Poznaniu, w którym pod płaszczykiem religii i ideowości kryją się agresja i zakłamanie. Warto też zwrócić uwagę na teksty Justyny Kopińskiej Polska odwraca oczy i Z nienawiści do kobiet. Czytelnicy odnajdują w nich ciemny obraz kraju: zależności politycznych, mowy nienawiści, patologii społecznych, homofobii i braku etyki zawodowej.

$\mathrm{Z}$ rankingu tłumaczonych żyjących polskich autorów non-fiction opublikowanym w lipcu 2014 roku przez magazyn „Press” wynika, że najczęściej przekładaną na języki obce polską reporterką jest Hanna Krall (70 tłumaczeń). Zaraz za nią znaleźli się Szczygieł (23 tłumaczenia) i Agata Tuszyńska (15 tłumaczeń) ${ }^{5}$. Zagraniczne rynki wydawnicze podbijają także książki Hugo-Badera i Artura Domosławskiego. Wysoko na liście „Pressu” znalazły się również teksty Jagielskiego i Tochmana, kontynuujące tradycję polskiego reportażu wojennego pod patronatem Ryszarda Kapuścińskiego. Wśród tłumaczonych na języki obce nie ma prawie w ogóle książek faktograficznych o Polsce. Jeśli nie liczyć książek Krall, współczesny polski reportaż w tłumaczeniu dotyczy przede wszystkim zagranicy ${ }^{6}$.

Nie ulega wątpliwości, że literatura faktu to jeden z najlepszych, najbardziej rozpoznawalnych rodzimych ,towarów eksportowych”. Od czasów Kapuścińskiego i Krall reportaż uchodzi za naszą specjalność. Jest chętnie promowanym za granicą — nasz kraj oprócz dotowania przekładów na inne języki, organizu-

${ }^{4}$ Zob. M. Ochwat: (Od)pamiętywanie, czyli o powinnościach dydaktycznych wobec wielokulturowości na przykładzie książki Marcina Kąckiego „Białystok. Biała siła, czarna pamięć”. $\mathrm{W}$ : (Od)pamiętywanie - gry z przeszłościa w literaturze dla dzieci i młodzieży. Red. B. Niesporek-Szamburska, M. Wójcik-Dudek. Katowice 2018, s. 279-299.

${ }^{5}$ Najczęściej thumaczone polskie książki non-fiction: Hanna Krall: Zdążý przed panem Bogiem (16 thumaczeń); Mariusz Szczygieł: Gottland (14 tłumaczeń); Hanna Krall: Taniec na cudzym weselu (10 thumaczeń); Wojciech Tochman: Jakbyś kamień jadła (10 tłumaczeń); Hanna Krall: Dowody na istnienie (8 thumaczeń); Hanna Krall: Król kier znów na wylocie (8 tłumaczeń); Agata Tuszyńska: Oskarżona Wiera Gran (8 tłumaczeń); Jacek Hugo-Bader: Biała goraczka (8 tłumaczeń); Artur Domosławski: Kapuściński: Non-Fiction (8 tłumaczeń). Zestawienie na podstawie rankingu autorów magazynu „Press” (lipiec—sierpień 2014) dotyczy książek pisarzy żyjących. http://culture.pl/pl/artykul/polskie-non-fiction-w-tlumaczeniu-i-nie\#rank [data dostępu: 18.02.2018]. Zob. więcej: http://www.press.pl/magazyn-press/artykul/36084,polskie-non-fiction-za-granica [data dostępu: 18.02.2018].

${ }^{6} \mathrm{http}: / /$ culture.pl/pl/artykul/polskie-non-fiction-w-tlumaczeniu-i-nie [data dostępu: 18.02.2018]. 
je zagraniczne wyjazdy na wieczory autorskie, a Instytut Reportażu prowadzi nawet Polską Szkołę Reportażu dla adeptów faktograficznej sztuki pisarskiej’.

\section{Laboratorium dydaktyczne}

W poczuciu misji edukacji polonistycznej oraz wartości, które wypływają z czytania literatury faktu przygotowującej uczniów do dojrzałego dialogu międzykulturowego, dobrego sąsiedztwa i gościnności, wybrałam ten gatunek jako główny temat prowadzonego przeze mnie przedmiotu - Konteksty kultury w szkole na V roku studiów, na kierunku filologia polska. Proponowane podczas zajęć teksty reportażowe dotyczyły problemów globalnych: największego kryzysu uchodźczego od czasów drugiej wojny światowej, historii uciekających przed wojną, prześladowaniami i biedą, tendencji ksenofobicznych wobec cudzoziemców, mowy nienawiści, ale i „,nowego rodzaju patriotyzmu” podszytego nacjonalizmem. Uważam bowiem, że szkoła, w duchu społecznej odpowiedzialności edukacji, nie może być obojętna na te zjawiska, a szczególnie — na co wskazywał Tadeusz Sławek w czasie swojego panelowego wystąpienia na III Kongresie Dydaktyki Polonistycznej w Lublinie — ,polonistyka powinna odnaleźć się w szerokim kręgu nauk społecznych. Szkoła nie działa przecież w próżni" . A reportaż zdaje się doskonale to zadanie wypełniać.

Krzysztof Koc już w 2007 roku w książce Czytanie świata. Reportaże Ryszarda Kapuścińskiego w edukacji polonistycznej zauważył, że praca z tekstami faktograficznymi w szkole ponadpodstawowej umożliwia doskonalenie nie tylko umiejętności analizowania i interpretowania świata, który ciągle się zmienia, ale uświadamia również konieczność posiadania wiedzy z zakresu historii, socjologii, antropologii, filozofii, religii i literatury ${ }^{9}$. Literatura ta pokazuje, jak integrować treści należące do różnych obszarów dyscyplinowych oraz jak tłumaczyć zmiany zachodzące w świecie, realizując wspomniany wcześniej postulat, który słusznie podnosił Sławek. Reportaż staje się ważnym głosem sprzeciwu wobec obojętności na to, co dzieje się aktualnie w Polsce i na świecie. A szkoła nie może się uchylić od obowiązku mówienia o tym, co dobre i złe,

${ }^{7}$ Zob. więcej: http://culture.pl/pl/artykul/polskie-non-fiction-w-tlumaczeniu-i-nie\#trank; http://instytutr.pl/pl/polska-szkola-reportazu/ [data dostępu: 18.02.2017].

${ }^{8}$ III Kongres Dydaktyki Polonistycznej. Katolicki Uniwersytet Lubelski Jana Pawła II. Polonistyka i świat wartości. Edukacja polonistyczna jako wartość, Lublin 22-25 listopada 2017 roku. Panel pt. Wartości i wartościowanie w polonistycznej dydaktyce uniwersyteckiej (sesja plenarna).

${ }^{9}$ K. Koc: Czytanie świata. Reportaże Ryszarda Kapuścińskiego w edukacji polonistycznej. Poznań 2007, s. 39-40. 
etyczne i haniebne, od oceny rzeczywistości, w której przyszło nam żyć. Moralne postępowanie nie jest przecież czymś oczywistym. Aksjologiczny wymiar kształcenia polonistycznego jest równie ważny, jak językowo-literacki. Kto wie, czy dziś nie staje się nawet ważniejszy...

Również Monika Wiszniowska w książce pt. Zobaczyć - opisać - zrozumieć. Polskie reportaże literackie o rosyjskim imperium ${ }^{10}$ wyjaśnia kwintesencję reportażu literackiego, pisząc, że zamyka się on w trzech tytułowych czasownikach: zobaczyć — opisać — zrozumieć. Przez prowadzące do zrozumienia opisywanie tego, co się widzi, ujawnia się istota edukacji polonistycznej i w ogóle humanistycznej. Skoncentrowana jest ona na rozwijaniu empatii uczniów oraz kształceniu zmierzającym do samodzielnego i krytycznego myślenia. „Myślenie uczuciami”, uczenie patrzenia na świat oczyma innych i własna refleksja nad rzeczywistością, to dziś nowe oblicze, ich współczesne DNA, Artes Liberales - przygotowujące młodzież do stawania się wolnymi obywatelami. A reporter pomaga nam zrozumieć świat. Najlepiej chyba ujął to Kapuściński, pisząc w Lapidariach: „reporter zagraniczny jest tłumaczem kultur" ${ }^{11}$. Istnienie w zgodzie obok siebie różnych dziedzictw kulturowych i cywilizacji to dziś w dobie przemian społecznych i politycznych, wzrostu skali oraz dynamiki przymusowych wędrówek ludności w poszukiwaniu schronienia, destabilizacji Bliskiego Wschodu, wojen i konfliktów w Afryce — problem, z którym najwyraźniej nie radzimy sobie zarówno w kraju, jak i na świecie, tworząc dystans, prowadząc do separacji, a w konsekwencji odrzucenia Innego.

Reportaż jest również gatunkiem modnym oraz docenianym w kraju i poza jego granicami, o czym pisałam już wcześniej. W pierwszej połowie XXI wieku nastąpiła wyraźna nobilitacja tej literatury, która utrzymuje się do dziś. Przypomnijmy: nagroda Nike w 2017 roku dla Cezarego Łazarewicza za książkę Żeby nie było śladów; Sprawa Grzegorza Przemyka — literacka Nagroda Nobla w 2015 roku dla reportażystki Swietłany Aleksijewicz; a od 2010 roku ustanowienie nagrody im. Ryszarda Kapuścińskiego przyznawanej najwartościowszym książkom reporterskim. Wobec tych wszystkich ważnych wyróżnień wydaje się, że literatura non-fiction jest wręcz wskazana i konieczna w szkole, a gdy spojrzymy na nową podstawę programową do języka polskiego w szkole ponadpodstawowej, okazuje się, że w kanonie lektur reportaży jest niewiele. W zakresie podstawowym ostał się m.in. w skromnych fragmentach Kapuściński z Podróżami z Herodotem i Krall ze Zdązyć przed Panem Bogiem. Uczeń poznaje również sam gatunek non-fiction jako tekst publicystyczny obok artykułu czy felietonu ${ }^{12}$, choć byłoby dobrze wspomnieć na języku polskim o naj-

${ }^{10}$ Zob. M. Wiszniowska: Zobaczyć - opisać - zrozumieć. Polskie reportaże literackie o rosyjskim imperium. Katowice 2017.

${ }_{11}$ R. Kapuściński: Lapidaria I-III. Warszawa 2008, s. 313.

$12 \mathrm{https} / / /$ men.gov.pl/wp-content/uploads/2018/01/zalacznik-nr-1.pdf [data dostępu: 7.02.2018]. 
nowszym reportażu literackim wydanym po 1989 roku i przeczytać kilka reprezentatywnych dla niego fragmentów.

\title{
O kontekstach kultury w szkole ponadpodstawowej - implikacje dydaktyczne
}

\begin{abstract}
Nikt nie wrzuca swoich dzieci do łodzi, jeśli woda nie jest bezpieczniejsza niż ląd.
\end{abstract} Warsan Shire ${ }^{13}$

Choćby mnie bóg znów jaki pogrążył w bałwany, Zniosę mężnie, w cierpieniach jam wypróbowany. Tylem już przebył, takie przechodził katusze Na wojnie i na morzu, że i to znieść muszę!

Homer $^{14}$

Do omawiania kryzysu migracyjnego zaproponowałam studentom reportaże polskie i zagraniczne, nie zaniedbując oczywiście innych gatunków, które o tym problemie również mówią. Podczas zajęć czytaliśmy wybrane fragmenty z literatury non-fiction, interpretowaliśmy je, a przede wszystkim zastanawialiśmy się, co można z nimi ,zrobić” w szkole. Dzieliliśmy się uwagami na temat tworzywa i budowy tekstów, wad i zalet wybranych fragmentów, ale również zbyt dużej dawki negatywnych emocji ze względu na dosadność słów, ekspresywność tekstu i autentyzm, które tego typu lektura niesie z sobą. Rozmawialiśmy o granicy brutalności opisów, mocy języka i przekazie, który trafi do ucznia.

Doszliśmy do kilku wniosków. Najpierw te dotyczące samego gatunku: wszechobecna kategoria Innego ${ }^{15}$ oraz pobudzanie refleksji nad problemami współczesnego świata powodują, że reportaż odpowiada na oczekiwania i potrzeby współczesnej generacji młodych. Zachętą dla uczniów do czytania tego gatunku są jego forma i cechy - używa aktualnych przykładów i współczesnego, prostego języka, charakteryzuje się wartką akcją i plastycznym obrazowaniem, przedstawia również dramatyzm wydarzeń z życia innych ludzi, który angażuje czytelnika ${ }^{16}$. Do tego jest on formą, w której autor stara się nie wyrażać

${ }^{13}$ Motto książki Patricka Kingsleya: Nowa Odyseja. Opowieść o kryzysie uchodźczym w Europie. Zob. więcej: P. Kingsley: Nowa Odyseja. Opowieść o kryzysie uchodźczym w Europie. Tłum. A. Paszkowska. Warszawa 2017, s. 7.

${ }^{14}$ Homer: Odyseja. Tłum. L. Siemieński. Warszawa 1990, s. 80.

${ }_{15}$ M. Zimnoch: Reportaż w płynnej nowoczesności. „Znak” 2012, nr 682, s. 117.

${ }^{16}$ Zob. K. Wolny-Zmorzyński: Reportaż jak go napisać? Poradnik dla stuchaczy studiów dziennikarskich. Warszawa 2004. Zob. rozdziały: Wyznaczniki reportażu i Systematyka reportażu. 
subiektywnej oceny, co może stymulować uczniów do kształtowania własnego zdania na dany temat i pozwolić rozwinąć myślenie krytyczne, a także zdolność do samodzielnego wyciągania wniosków z prezentowanych historii, popartych lekturowymi argumentami. Plusem tej propozycji lekturowej jest brak opracowań, które nazbyt ułatwiają uczniom obcowanie z książką, na co zwracała uwagę Krystyna Koziołek w książce Czas lektury ${ }^{17}$.

Biorąc pod uwagę powyższe argumenty związane $\mathrm{z}$ atutami reportażu zdaniem młodszych czytelników oraz tematy aktualnie bardzo istotne: migracja i uchodźstwo, postanowiłam przez semestr realizować cykl spotkań na temat „dobrego bycia razem”. Oprócz treści przewidzianych przy wprowadzaniu kontekstów kultury, takich jak: style w architekturze, sztuka czytania obrazów, blok zajęć poświęciłam odpowiedziom na pytania: jak uczyć o problemie migracji i uchodźstwa na lekcji języka polskiego? Jakie teksty do tego wybierać? Jakie filmy ukazują ten problem? Czym się kierować przy ich wyborze? W trakcie ćwiczeń omawialiśmy więc następujące zagadnienia: kim jest uchodźca, kim imigrant, a kim azylant; czy kategorie te łatwo od siebie odróżnić i czy wyodrębnianie ich jest słuszne z punktu widzenia etycznego ${ }^{18}$. Poznawaliśmy również „nowe” kategorie: imigrant klimatyczny ${ }^{19} \mathrm{i}$ egzystencjalny ${ }^{20}$, ale rozmawialiśmy także o wielokulturowości, inności, filozofii dialogu Emmanuela Lévinasa, socjologii Zygmunta Baumana z kluczową publikacją Obcy u drzwi, o tendencjach nacjonalistycznych w Polsce i w Europie, a także o sacrum z punktu widzenia różnych religii - czyli o wszystkim tym, co dotyczy różnic i podobieństw w obszarze tożsamości kulturowej. Oglądaliśmy fragmenty filmów o sytuacji w Polsce, kiedy to nasi rodacy musieli uciekać do innych krajów: 300 mil do nieba, Ostatni prom, analizowaliśmy teledyski M.I.A. i język popkultury mówiący o uchodźcach. Czytaliśmy fragmenty książek: Wykluczeni Domosławskiego, Jarosława Mikołajewskiego Wielki Przyplyw, Dionisosa Sturisa Nowe

17 Zob. K. Koziołek: Czas lektury. Katowice 2017.

18 Kategorie: ,uchodźca” i ,imigrant” są istotne z punktu widzenia ram prawnych czy administracyjnych, domagają się jednak dużo głębszej refleksji. „Selekcja ludzi” i ich sytuacji życiowych na jakiekolwiek kategorie jest bardzo złożona, o czym wspominał Artur Domosławski w reportażu Wykluczeni. Pisze on: „Bliski ogląd losów konkretnych ludzi nie pozwala utrzymać tego podziału. Sytuacje życiowe konkretnych ludzi nie mieszczą się w wąskich ramach definicji »migranta ekonomicznego« bądź »uchodźcy«" (A. Domosławski: Wykluczeni. Warszawa 2016, s. 371). Trzeba więc również wyjaśniać ich warunki egzystencjalne i odpowiadać na trudne pytania: czy zawsze radykalnie różnią się od siebie sytuacje uchodźców i imigrantów? Czy z punktu widzenia moralnego taki podział jest w ogóle do obronienia?

19 Temat uchodźców klimatycznych podejmuje Domosławski, pisząc o wojnach klimatycznych i nowej Zagładzie. Zob. ibidem, s. 386.

${ }^{20}$ „Ludzie niepodpadający pod ogólnie przyjętą definicję uchodźcy, uciekają jednak przed biedą lub brakiem perspektyw, są migrantami tyleż ekonomicznymi, co egzystencjalnymi”. J. Fudge: Granice - w tym samym mieście, pod tym samym niebem. W: W tym samym mieście, pod tym samym niebem... Red. A. Konik. Warszawa 2016, s. 11. 
życie. Jak Polacy pomogli uchodźcom z Grecji. Na temat tej literatury powstało zresztą sporo szkiców interpretacyjnych ${ }^{21}$, które nauczyciel z powodzeniem może wykorzystać do przygotowania się do lekcji. Warto także zapoznać się z numerem „Polonistyki. Innowacji” w całości poświęconemu migracjom i ich konsekwencjom ${ }^{22}$.

Na początku pierwszych zajęć przeprowadziłam ankietę, w której zapytałam studentów o najbardziej aktualne współczesne problemy, które powinny być podejmowane na lekcjach języka polskiego na podstawie tekstów kultury. Wśród wielu odpowiedzi znalazły się: automatyzacja życia; komunikacja w Internecie; cyberprzemoc; uzależnienia (w tym te nowoczesne); anoreksja; konflikty $w$ domu; ekologia; wybór życiowej drogi. Jednocześnie prawie w każdej ankiecie studenci wskazywali na: rasizm; wielokulturowość; ksenofobię; homofobię; nietolerancję; szacunek dla każdego człowieka; dyskryminację rasowa i religij$n a$; hejt w sieci; mowe nienawiści; problem wykluczenia; odpowiedzialność za siebie $i$ za innych; kryzys migracyjny; alienacje jednostki i emigracje. Wszystkie te zagadnienia można w jakiejś mierze realizować na języku polskim, odwołując się do podstawy programowej i aktualnego kanonu szkolnych lektur, warto jednak tematy te widzieć szerzej i nowocześniej ${ }^{23}$. Stąd na pierwszych zajęciach przedstawiłam wykaz zalecanej najnowszej literatury niefikcyjnej, a studenci wybierali na zaliczenie przedmiotu jedną pozycję lekturową. Wśród wielu proponowanych przeze mnie reportaży znalazły się m.in:

- Wolfgang Bauer: Przez morze. Z Syryjczykami do Europy;

- Jarosław Mikołajewski: Wielki przyptyw;

- Małgorzata Szejnert: Wyspa klucz;

- Marta Mazuś: Król kebabów i inne zderzenia polsko-obce;

- Wojciech Tochman, Katarzyna Boni: Kontener;

- Barbara Demick: Światu nie mamy czego zazdrościć. Zwyczajne losy mieszkańców Korei Pótnocnej;

- Artur Domosławski: Wykluczeni;

${ }^{21}$ Zob. więcej: M. Ochwat: O uchodźcach z Grecji (i nie tylko) na lekcji we wspótczesnej szkole - Nowe życie. Jak Polacy pomogli uchodźcom z Grecji Dionisiosa Sturis. „Postscriptum Polonistyczne” 2018, nr 2, s. 207-223; Eadem: O społecznej odpowiedzialności edukacji polonistycznej $i$ (nowych) lekturach na rzecz wychowania do pokoju. „Czas Kultury” 2018, nr 3, s. 96-104; M. Szopiński: Jak czytaliśmy teksty o uchodźcach Jarosława Mikołajewskiego? Refleksje nauczyciela po lekcji akademickiej. „Polonistyka. Innowacje” 2017, nr 6, s. 207-215.

${ }^{22}$ Zob. „Polonistyka. Innowacje” 2017, nr 6.

${ }^{23}$ Zob. A. Janus-Sitarz: Arcydzieła niepoprawne, czyli o potrzebie krytycznego czytania. W: W trosce o dobra edukację. Teksty dedykowane profesor Jadwidze Kowalikowej. Red. A. Janus-Sitarz, M. Madejowa. Kraków 2009, s. 412-422; A. Adamczuk-Stemplewska: Wielokulturowość w polskiej literaturze najnowszej jako przedmiot ksztatcenia polonistycznego na etapie liceum. W: Wyczytać świat - międzykulturowość $w$ literaturze dla dzieci i młodzieży. Red. B. Niesporek-Szamburska, M. Wójcik-Dudek. Katowice 2014, s. $311-323$. 
- Dionisios Sturis: Nowe życie. Jak Polacy pomogli uchodźcom z Grecji;

- Aneta Prymaka-Oniszk: Bieżeństwo 1915. Zapomniani uchodźcy ${ }^{24}$.

Studenci mogli również wskazywać wybrane przez siebie reportaże. Praca zaliczeniowa polegała na przygotowaniu pomysłu na lekcję języka polskiego (w formie konspektu) na podstawie fragmentów wybranych reportaży oraz zarekomendowaniu grupie przeczytanego tekstu, wskazaniu jego szerszych możliwości wykorzystania w szkole.

Ze względu na ograniczenia objętościowe nie mogę przytoczyć w artykule w całości wszystkich pomysłów studenckich na lekcję polskiego w szkole ponadpodstawowej. Wybrałam więc jeden (wraz z analizowanymi fragmentami z książek), który ma na celu zwrócić uwagę uczniów na podobieństwo sytuacji imigrantów (w tym także Polaków), uciekających kiedyś z powodu wojny czy biedy, do współczesnej sytuacji uchodźców i imigrantów z krajów Bliskiego Wschodu, a tym samym uwrażliwić ich na los jednostek i całego narodu. Oprócz przywołanego w artykule pomysłu, studenci przygotowali również inne projekty lekcji. Zaproponowali oni następujące tematy:

— Trudna droga do kraju wolności — refleksje wokół reportażu Małgorzaty Szejnert pt. Wyspa klucz;

- Przez morze. Z Syryjczykami do Europy. Wokół tematyki migracji (na podstawie reportażu Wolfganga Bauera Przez morze. Z Syryjczykami do Europy);

— „Życie” języka polskiego. Czy zmiany cywilizacyjne warunkują podejście do słowa? (lekcja wokół etymologii i znaczeń słów: „bieżeniec”, „refugee”, „uchodźca");

— „Najczęściej wolność można dotknąć tylko w sieci, w mediach społecznościowych, zależnie od megabajtów" - czyli czym jest Instagram dla Emiratek w książce Aleksandry Chrobak pt. Beduinki na Instagramie;

- Sztuka reportażu na przykładzie Król kebabów i inne zderzenia polsko-obce Marty Mazuś;

— Współczesne wybory Majów — kultura i tradycja w książce Weroniki Milczewskiej pt. Na początku jest koniec;

- Reportaż, tekst jak każdy inny? Dariusza Rosiaka Ziarno i krew. Podróż śladami bliskowschodnich chrześcijan;

— W kraju wielkiego blefu — reportaż z Korei Północnej. John Sweeney — Korea Pótnocna. Tajna misja w kraju wielkiego blefu;

${ }^{24}$ W. Bauer: Przez morze. Z Syryjczykami do Europy. Tłum. E. Kalinowska. Wołowiec 2016; J. Mikołajewski: Wielki przyptyw. Warszawa 2015; M. Mazuś: Król kebabów i inne zderzenia polsko-obce. Warszawa 2015; W. Tochman, K. Boni: Kontener. Warszawa 2014; D. Sturis: Nowe życie. Jak Polacy pomogli uchodźcom z Grecji. Warszawa 2016; A. Prymaka-Oniszk: Bieżeństwo 1915. Zapomniani uchodźcy. Wołowiec 2016; B. Demick: Światu nie mamy czego zazdrościć...; A. Domosławski: Wykluczeni...; M. Szejnert: Wyspa klucz. Kraków 2009. 
— Próbówka europejskiej przyszłości czy nieudany eksperyment? Szwedzka wizja świata na podstawie cyklu reportaży Katarzyny Tubylewicz;

— Zwyczajne losy mieszkańców Korei Północnej Beaty Demick pt. Światu nie mamy czego zazdrościć. Zwyczajne losy mieszkańców Korei Pólnocnej;

- Najwyższa cena, to cena sprzeciwu (na podstawie reportażu Samar Yazbek Przeprawa. Moja podróż do pękniętego serca Syrii);

— Wokół idei tolerancji na świecie (na podstawie książki Michaela Walzera O tolerancji);

- Niby obcy, a tak podobny... Praca z fragmentami książki Lepiej, byś tam umart Szczepana Twardocha i Mameda Khalidova;

— Plaża turystów — brzeg martwych, czyli refleksje wokół reportażu Wielki przyplyw Jarosława Mikołajewskiego.

Intencją moją nie było pokazanie perfekcyjnej lekcji polskiego. Chciałam raczej zwrócić uwagę studentów — przyszłych nauczycieli — na fakt, że edukacja polonistyczna może, a nawet musi mówić językiem lektur o rzeczach ważnych współcześnie; takim tematem niewątpliwie jest dramat uchodźców. Zależało mi, żeby studenci, jako przyszli pedagodzy, na lekcji starali się wychodzić poza przyjęte schematy. Jak się wydaje, odpowiedni wybór literatury najnowszej to chyba najlepszy sposób na wywoływanie emocji, wychowywanie myślących obywateli oraz w ogóle na zachętę do czytania (zob. propozycja wybranej lekcji w aneksie artykułu).

W ankiecie ewaluacyjnej ${ }^{25}$, podsumowującej semestr zajęć z reportażem opowiadającym o współczesnej migracji, studenci wskazywali następujące korzyści z omawiania tego gatunku w przestrzeni lekcyjnej:

- przybliza obce kultury, środowiska, tradycje;

- pokazuje problemy świata z różnych perspektyw;

- nawiazuje do współczesnej bliskiej uczniom problematyki w przeciwieństwie do często już nieaktualnej i napisanej archaicznym językiem literatury;

- poszerza wiedze o świecie;

- uczy wrażliwości;

- rozbudza empatię;

- pomaga ksztattować opinię uczniów;

- dostarcza przyjemności z lektury.

Adepci polonistyki wielokrotnie podkreślali, jak ważne jest widzenie świata z różnych perspektyw i stron. Co więcej, poszerzanie wiedzy o obce kultury i tradycje uznali za obowiązek edukacji polonistycznej. I nie chodzi tu tylko

25 Jedenaścioro studentów wypełniło ankietę z następującymi pytaniami: 1. Wymień 3 najistotniejsze cechy reportażu, stanowiące o jego istocie. 2. Jakie funkcje może spełniać reportaż? 3. Jakie elementy reportażu dyskwalifikują go w Twoich oczach? 4. Czy będziesz wykorzystywał/ ła fragmenty reportażu w pracy w szkole? Zob. podobne badania dotyczące reportażu radiowego wśród studentów: K. Klimczak: Jak go styszą? Studenci o reportażu radiowym. Uwagi o instytucji stuchacza. „Acta Universitatis Lodziensis. Folia Litteraria Polonica” 2008, nr 11, s. 287_299. 
o funkcję poznawczą; idzie raczej o coś więcej: o wychowanie, krytyczne myślenie, ale również o sam akt lektury. Moją uwagę zwróciły również wypowiedzi dotyczące potrzeby kształtowania w uczniach empatii — jest ona, jak pokazują badania ${ }^{26}$, raczej słabą stroną Polaków. Warto więc wybierać takie książki, których bohaterowie różnią się od uczniów — myślą inaczej, pochodzą z innego kręgu kulturowego, borykają się z kompletnie innymi niż my problemami.

$\mathrm{Na}$ ostatnie pytanie: czy studenci będą korzystać z fragmentów reportaży w szkole, wszyscy odpowiedzieli twierdząco. Wprawdzie wśród odpowiedzi na pytanie, co dyskwalifikuje reportaż, dostrzegli oni następujące „słabsze” strony gatunku:

- odstęstwo od prawdy;

— zbyt duży subiektywizm;

- możliwość koloryzowania;

- zbyt kontrowersyjna tematyka;

- reportaż może być ciekawszy niż inne obowiazkowe teksty.

Stronniczość autora, fałsz czy podkoloryzowanie dyskwalifikują tekst w oczach studentów. W reportażu ważna jest przecież prawda, autentyzm, rzetelność i szczerość ${ }^{27}$. Dostarcza on wiedzy o rzeczywistości, na podstawie której formułuje się opinie i podejmuje działania.

Wypowiedź, że ,reportaż może być ciekawszy niż inne obowiązkowe teksty" jest dyskusyjna, jeśli potraktujemy wyrabianie nawyku czytania u dzieci i młodzieży jako priorytet dydaktyki literatury — o co apelowała Koziołek. Wydaje mi się, że tok myślenia studenta był jednak trochę inny: sporo lektur jest archaicznych, nudnych i całkowicie niezrozumiałych dla młodego odbiorcy z powodu niedzisiejszego języka i tematu. A teksty reportażowe są w większości interesujące, napisane prostym stylem, do tego są aktualne, stają się więc „niebezpieczną” alternatywą dla szkolnego przymusowego kanonu lektur. Nie-

${ }_{26}$ Zob. http://www.focus.pl/artykul/czy-polakom-brakuje-empatii-wyniki-tych-bada-nie-s-najlepsze [data dostępu: 27.12.2017]. Zob. więcej na ten temat: http://www.wysokieobcasy.pl/ wysokie-obcasy/7,115167,20918341,najwieksze-swiatowe-badanie-empatii-co-z-niego-wynika. html [data dostępu: 27.12.2017]. W 63 krajach przebadano ponad 100 tys. ludzi w wieku 18 —90 lat. Rozmach eksperymentu robi wrażenie. Dane zebrano od internautów, którzy zechcieli wypełnić ankiety umieszczone na niezależnej stronie internetowej. Kwestionariusze skonstruowano w języku angielskim i udało się ich zebrać 104365 sztuk. Ponad 61\% respondentów zadeklarowało się jako mężczyźni, a 74\% odpowiedzi spłynęło od mieszkańców USA. Można wywnioskować, że ankietę na stronie WWW i w języku angielskim wypełnili raczej młodsi respondenci, co nie do końca daje wiarygodny wynik.

27 A. Leszczyński: Polska szkoła zmyślania http://krytykapolityczna.pl/kultura/czytaj-dalej/ leszczynski-polska-szkola-zmyslania/ [data dostępu: 25.02.2017]; Polska szkoła reportażu = polska szkoła zmyślania?. Dyskutują M. Szczygieł, A. Leszczyński i T. Stawiszyński. http:// audycje.tokfm.pl/podcast/Polska-szkola-reportazu-polska-szkola-zmyslania-Dyskutuja-Mariusz-Szczygiel-Adam-Leszczynski-i-Tomasz-Stawiszynski/50160 [data dostępu: 25.02.2017]. 
stety, wraz z nową reformą oświaty wolność czytania praktycznie zniknęła ze szkół. Przeładowany spis lektur nie sprzyja sięganiu po książkę dla przyjemności, ogranicza lekturę prywatną, żeby nie powiedzieć, że w ogóle nie ma czasu na uważne czytanie.

Analiza ankiet ewaluacyjnych i blisko półroczna praca ze studentami pozwoliły stwierdzić, że tekst reportażowy może być ważnym wytworem kultury analizowanym i interpretowanym w szkole. Dzięki niemu przyszli nauczyciele dostrzegają aksjologiczny wymiar kształcenia. Dotykają oni tym samym sedna nie tylko edukacji polonistycznej, lecz generalnie humanistycznej. Nauki humanistyczne - pisze Michał P. Markowski w Polityce wrażliwości. Wprowadzenie do humanistyki - powinny przygotować kolejne pokolenie do myślenia tyleż o sobie, co o innych (empatia), tyleż o tym, co jest, co o tym, co mogłoby być (wyobraźnia), i tyleż o tym, jak jest, co o tym, jak mogłoby być (krytyka)28. Dzięki czytaniu reportaży możemy to wszystko, co wymienia Markowski osiągnąć. Książki bowiem, które „obchodzą ludzi”, dokonują „,przemiany”, jak pisała Martha C. Nussbaum w tekście Czytać, aby żyć ${ }^{29}$.

\section{Reportaże o dramacie uchodźców}

Koc w artykule Szkolna narracja o uchodźcach a formacyjny wymiar edukacji polonistycznej ${ }^{30}$ stawia istotne i niełatwe pytanie o cel, w jakim powinno się na lekcjach polskiego poruszać temat dramatu uchodźców. Tym samym skłania do zastanowienia się nad sensem formacyjnej funkcji nauczania, warunkami realizacji i przyświecającym jej założeniom. Poznański badacz argumentuje realizowanie formacyjnych zadań w szkolnej polonistyce koniecznością wprowadzenia problematyki aksjologicznej:

Refleksja nad dramatem uchodźców [...] powinna być namysłem nad charakterem norm etycznych i relacjami społecznymi, nad znaczeniem takich wartości, jak np. wolność, solidarność, odpowiedzialność, bezpieczeństwo, rodzina, dom, ojczyzna, religia, europejskość, a także nad konflikta$\mathrm{mi}$ i napięciami wynikającymi ze spotkania $\mathrm{z}$ innym ${ }^{31}$.

${ }_{28}$ M.P. Markowski: Polityka wrażliwości. Wprowadzenie do humanistyki. Kraków 2013, s. 24.

${ }^{29}$ M.C. Nussbaum: Czytać, aby żyć. „Teksty Drugie” 2002, nr 1/2, s. 7-24.

${ }^{30}$ K. Koc: Szkolna narracja o uchodźcach a formacyjny wymiar edukacji polonistycznej. „Polonistyka. Innowacje” 2017, nr 6, s. 99.

${ }^{31}$ Ibidem, s. 104. 
W naszym przypadku studenckie spotkania z reportażem dały podobną odpowiedź — potrzeba spoglądania na świat uchodźców za pośrednictwem wartości. Rozmowy prowadziły nas ku refleksji, że szkoła powinna podejmować temat kryzysu migracyjnego wprost i pośrednio. Pośrednio w powrocie do takich wartości, jak: szacunek, godność, solidarność, gościnność, dialog z Innym i odpowiedzialność za Innego, wolność kontra zniewolenie, tożsamość, ale i dom, rodzina, bezpieczeństwo, praca, samorealizacja. Wprost - w indywidualnych narracjach, które są skontrastowane z szerszą narracją o uchodźcach i imigrantach, znaną nam z mediów oraz debat politycznych. Narracja ta zresztą nie zawsze jest prawdziwa, często wyrwana z kontekstu, opatrzona uproszczonymi czy powierzchownymi komentarzami. Analizując indywidualne przypadki bohaterów, młodzież ma szansę spojrzeć krytycznie również na stereotypowe przedstawianie uchodźców, jako samotnych i silnych mężczyzn, niepodejmujących pracy i niemyślących o powrocie do swego kraju ${ }^{32}$. Takie lekcje zatem to również ćwiczenie w rozbijaniu niebezpiecznych uogólnień w formułowanych opiniach.

Reportaż może pomóc uczniom, ale i dorosłym, sięgnąć po książkę, która uczy dobrego sąsiedztwa w warunkach powszechnej gościnności. Taka postawa jest nam bardzo potrzebna w dzisiejszych czasach, w których wielu z nas straciło „orientację”, stało się obojętnymi na dramat ludzi żyjących obok nas. O grzechu obojętności mówił na wyspie Lampedusa papież Franciszek:

Wielu z nas, włącznie ze mną, jesteśmy zdezorientowani, nie zwracamy już uwagi na świat, w którym żyjemy, nie troszczymy się, nie strzeżemy tego, co stworzył Bóg dla wszystkich i nie jesteśmy nawet zdolni do wzajemnej troski o siebie [...]. Prośmy Pana, aby wymazał to, co z Heroda pozostało także w naszym sercu; prośmy Pana o łaskę płaczu nad naszą obojętnością, nad okrucieństwem, jakie jest w świecie, w nas, również w tych, którzy bezimiennie podejmują decyzje społeczno-gospodarcze, które otwierają drogę do podobnych dramatów. [...] Prosimy o przebaczenie dla tych, którzy wygodnie zamknęli się we własnym dobrobycie, który znieczula serce; prosimy o wybaczenie dla tych, którzy przez swoje decyzje na poziomie światowym stworzyli sytuacje, które prowadzą do tych dramatów $[\ldots]^{33}$.

Polonistyka, jeśli chce mówić mądrze o świecie, a powinna — bo przecież „dobrze się myśli literaturą" - musi znajdować się w centrum dziejącego się

${ }^{32}$ Zob. R. Cekiera: Terroryści, tchórze i lenie - konstruowanie wizerunku uchodźców za pomoca memów internetowych. „Kultura. Media. Teologia” 2017, nr 29, s. 69-85.

$33 \mathrm{http}: / /$ www.radiomaryja.pl/kosciol/homilia-ojca-swietego-franciszka-wygloszona-na-wyspie-lampedusa/ [data dostępu: 25.02.2017]. 
„tu i teraz”, nie powinna zamykać się w wieży z kości słoniowej. Czytanie reportaży na temat dramatu innych, w tym uchodźców i imigrantów, w jakiejś mierze przeciwdziała obojętności. Warunkiem przeczytania jest przecież, jak pisze Markowski, wtargnięcie w mój świat, czytanie musi więc angażować, „naruszać słowem”, wzywać do reakcji. Inaczej gubi swoją istotność, tym samym jedną z najważniejszych ról, jaką ma do wypełnienia.

\section{Aneks}

\section{Propozycja lekcji studenckiej}

Konspekt lekcji poświęconej fragmentom reportażu Małgorzaty Szejnert pt. Wyspa klucz Aleksandra KRÓL, filologia polska, II rok MU

\section{Uzasadnienie}

Niniejszy konspekt porusza kwestię migracji oraz problemów z nią związanych — zarówno dla przybyszy, jak i przyjmujących obywateli innych narodowości. Zajęcia skupiają się na poznaniu procedur, jakie musieli przejść imigranci z Europy, Azji czy Afryki przybywający do Stanów Zjednoczonych — kraju uznawanego na przełomie XIX i XX wieku na świecie za symbol wolności, niepodległości i dobrobytu.

Uczniowie mają ocenić, czy daleko idąca ostrożność w przyjmowaniu ludności była uzasadniona oraz czy imigranci podczas podróży do „kraju marzeń” byli traktowani z poszanowaniem ich wolności i godności osobistej. Analiza podanych fragmentów pozwala na skojarzenia uprzedmiotowionego stosunku personelu amerykańskiego stacji Ellis Island do imigrantów z praktykami nazistów w obozach koncentracyjnych w czasach drugiej wojny światowej oraz ze współczesną sytuacją uchodźców z obszaru Bliskiego Wschodu.

Lekcja ma zachęcić uczniów do otwartości na kwestie inności, gdyż w zależności od punktu widzenia również my, Polacy, byliśmy (a może nadal jesteśmy) „inni” dla Zachodu. Ponadto istotnym celem zajęć jest zaakcentowanie znaczenia wolności dla współczesnego człowieka.

Uczniowie w czasie lekcji mają możliwość doskonalenia publicznego wygłaszania swojej opinii podczas dyskusji, precyzyjnego określania własnego stanowiska, ale także wczucia się w sytuację obu stron — Innego i urzędu imigracyjnego. 
Fragment reportażu

\section{Załącznik nr 1}

Rozpoznanie źle zbudowanej, wadliwej lub zdezelowanej istoty ludzkiej nie jest trudniejszym zadaniem niż rozpoznanie tandetnego lub wadliwego automobilu. Wymaga to oczywiście pewnego treningu i doświadczenia, ale w każdym wypadku mniejszą trudność sprawia dostrzeżenie, że coś jest nie w porządku, niż określenie i wykazanie, co mianowicie jest nie w porządku. Co się tyczy imigrantów, można z tą metaforą pójść dalej. Człowiek, który idzie do lekarza, pomaga mu zazwyczaj odnaleźć przyczynę kłopotów, opowiadając o swych subiektywnych objawach. Obcokrajowca, który stawia się przed urzędnikiem imigracyjnym, interesuje zaś zazwyczaj tylko to, by go przekonać, że wszystko jest dobrze, i można by z równym skutkiem marnować czas, czekając na opowieść automobilu o jego uczuciach, jak liczyć na pomoc diagnostyczną w postaci subiektywnych objawów chorego imigranta [...].

Imigranci weszli do wielkiego westybulu na parterze głównego gmachu stacji, a teraz wspinają się na pierwsze piętro (w amerykańskim porząd$\mathrm{ku}$ - na drugie) pod uważnym wzrokiem lekarzy, którzy, jak już wiemy, noszą uniformy przypominające mundury wojskowe. Przybysze z podbitych państw Europy niczego i nikogo nie boją się bardziej niż mundurowych, uosabiających opresję $\mathrm{w}$ ich miastach i wioskach, więc czynią wszystko, by zniknąć z pola widzenia, schować się za kimś większym, wsiąknąć w kapotę, zasłonić tobołkiem. Te naiwne sposoby zostały szybko odkryte, skatalogowane, opisane w instrukcjach i lekarze dobrze wiedzą, kogo wyłuskać z tłumu do dalszych badań. Lekarz inspekcyjny, który obrzuca imigranta szybkim spojrzeniem, musi zwrócić uwagę na sześć elementów: skórę głowy, twarz, szyję, ręce, sposób chodzenia i ogólną kondycję — fizyczną i psychiczną.

Jeśli któryś z tych elementów nie jest widoczny gołym okiem, lekarz zatrzymuje imigranta, aby się upewnić, czy nie ma w tym czegoś podejrzanego.

Wysoki kołnierz. Należy go rozpiąć i sprawdzić, czy nie czai się pod nim wole lub wrzód.

Kapelusz. Kryje często strupień woszczynowy albo grzybicę.

Bujne loki. Jak wyżej.

Czapka z daszkiem nasunięta na oczy. Może osłaniać zapalenie spojówek albo jaglicę. 
Ręka schowana pod płaszczem, szalem, bagażem. Może się okazać zdeformowana, sparaliżowana, bez palców, ze strupniem.

Bagaże. Mogą maskować wady postawy. Imigrant musi zostawić je na podłodze i przejść bez nich około dziesięciu stóp.

Dzieci powyżej dwóch lat uczepione matki. Matka ma postąpić jak wyżej.

Obliczono, że w dniach większego napływu, kiedy Ellis przyjmuje cztery_pięć tysięcy osób, każdy lekarz ma na zeskanowanie wzrokiem jednego człowieka mniej więcej sześć sekund. O doktorach inspekcyjnych, zwanych także liniowymi, mówi się coraz częściej — sześciosekundowi.

Jeżeli sześciosekundowy coś zauważy i uzna, że potrzebne są dalsze dokładne badania, musi im nadać kierunek za pomocą kredy. Na ubraniu osoby podejrzanej o defekt psychiczny rysuje X. Jeśli defekt psychiczny jest bardzo prawdopodobny - ujmuje X w kółko. B to grzbiet (back), $\mathrm{C}$ - zapalenie spojówek (conjunctivitis), CT — jaglica (trachoma), E inne choroby oczu (eyes), F — twarz (face), Ft — stopy (feet), G - wole (goiter), H - serce (heart), K - przepuklina (hernia), N — szyja (neck), $\mathrm{P}$ - badanie i płuca (physical and lungs), Pg — ciąża (pregnancy), Sc skóra głowy (scalp), S - otępienie (senility).

Czasem nie stosuje się kamuflażu, lecz maluje kredą całe słowo, na ogół na piersiach lub plecach imigranta: ręka, noga, skóra, paznokcie (krótki rzeczownik: nails) [...].

Do 1998 roku historia wyspy nie znała przypadku, by komuś udało się wymknąć z niewoli znaków kredowych. W tymże roku przypłynęła na Ellis osiemdziesięcioczteroletnia Hiszpanka Espuga Manuela Carnero. Wyemigrowała do Ameryki w 1920 roku z matką i bratem. Miała sześć lat, ale zapamiętała, że inspektor oznaczył kredą płaszczyk braciszka. Matka tak szybko i zręcznie ściągnęła z niego ten płaszcz, że nikt niczego nie zauważył. [...] W każdym razie nie wycofano chłopca z szeregu i nie rozłączono z rodziną. Espuga Manuela Carnero przypłynęła na Ellis, by to opowiedzieć i nagrać, ponieważ nigdy nie jest za późno na mówienie innym, że trzeba walczyć do końca, nawet gdy opór wydaje się beznadziejny ${ }^{34}$.

${ }^{34}$ M. Szejnert: Wyspa klucz..., s. 68-70. 


\section{Załącznik nr 2}

Stój z fasola, steerage

Siedemnastego kwietnia 1907 roku do portu nowojorskiego przybija jedenaście tysięcy siedmiuset czterdziestu siedmiu imigrantów. Jak to pokazać sto lat później szkolnym wycieczkom na Ellis Island, by poruszyć ich wyobraźnię? Specjaliści od edukacji zaproponowali, by wypełnić ogromny słój drobną fasolką w wielu kolorach i zawiesić nad nim pytanie: Jak sadzisz, czy byto ich tylu?.

To jest dzień szczytu i rok szczytu. Tego roku do USA przypływa milion dwieście osiemdziesiąt pięć tysięcy trzysta czterdzieści dziewięć osób (w tym do portu w Nowym Jorku milion cztery tysiące osiemset pięćdziesiąt sześć). Inspektorzy imigracyjni z Ellis Island kontrolują pasażerów $\mathrm{z}$ trzech tysięcy ośmiuset osiemnastu statków.

Amerykańscy karykaturzyści mają co robić. „New York Evening World” pokazuje nam krótką wymianę zdań między potężnym Wujem Samem w kabacie usianym gwiazdami, z napisem United States na kołnierzu, a wąsatym człowieczkiem w czepku $\mathrm{z}$ falbanką, trzymającym przed sobą becik z etykietą imigranci w tym tygodniu. Wuj Sam opiera wielką łapę na zawiniątku i woła do pielęgniarki, czyli komisarza Watchorna: Nie mów $m i$, że to trojaczki! A wąsata pielęgniarka, zezując ze strachu okrągłymi oczkami, odpowiada: Trojaczki! Ich jest trzydzieści pięć tysięcy!.

Liczebność statków, udogodnienia techniczne i cywilizacyjne powinny sprzyjać poprawie warunków podróży, ale napór mas imigrantów na linie okrętowe, rosnący popyt na bilety sprawiają, że rejs na steerage jest ciągle ciężką próbą dla ciała i charakteru. Steerage staje się tematem dla polityków, pisarzy i prasy.

Znany nam już pastor i pisarz Edward A. Steiner wykupuje dla siebie bilety w kabinach, ale spędza czas z imigrantami na międzypokładach i zapisuje, co widział. Na statku Staatendam kradnie nocą w drugiej klasie wodę dla złaknionych pasażerów steerage. Na statku Nordam pilnuje, by umierającego rosyjskiego chłopca wyniesiono z czeluści dolnego pokładu na świeże powietrze i nie wepchnięto na dół z powrotem, lecz położono w szpitalu. Notuje, że na eleganckim, obszernym statku Kaiser Wilhelm II Północnoniemieckich Linii Lloyda dziewięciuset pasażerów steerage stłoczono jak bydło: nie mogą ani oddychać na dole, gdzie brak powietrza, ani wyjść na pokład przeznaczony dla lepszych klientów. 
Zwraca uwagę na nieuczciwość linii okrętowych, które biorą za łóżko $\mathrm{w}$ drugiej klasie zaledwie dwa razy więcej niż za pryczę na steerage i za tę podwójną cenę ofiarowują sześć razy więcej miejsca, względną prywatność i porządną obsługę.

Steerage powinno być i mogłoby być obalone przez prawo - pisze i dodaje - To prawda, że wtoski czy polski chtop nie przyzwyczait się może $w$ domu do lepszych warunków i nie byłby szczęśliwszy $w$ lepszym otoczeniu, nie wiedzac, jaki czynić z niego użytek, traktowanie go jednak jak zwierzęcia, gdy do nas przybywa, jest złym wprowadzeniem w nasze życie.

Polski chłop mógłby jednak zaskoczyć Edwarda Steinera wiedzą o steerage, przekazywaną sobie wzajemnie przez rodziny i sąsiadów.

$[\ldots]$

Poseł Adolph J. Sabath ze stanu Illinois oskarża w Kongresie linie okrętowe o egoizm i hipokryzję. Leją one krokodyle tzy, jak to zwykle czynia nieszczęsne i ciemiężone korporacje, gdy wymaga się od nich, by pomniejszyły swoje nadużycia i polepszyły warunki klientom. Amerykanie lepiej dbają o bydło, które wysyłają ze swoich portów, niż linie okrętowe o pasażerów. Departament Rolnictwa USA kontroluje, czy zwierzęta mają na statkach dosyć miejsca, powietrza i wody, podczas gdy wielkie linie oceaniczne stłaczają po dwustu pasażerów steerage na ciasnej przestrzeni, która służy za wspólną sypialnię, jadalnię i miejsce dziennego pobytu. Piętrowe łóżka stoją w blokach po trzydzieści dwa, brakuje urządzeń sanitarnych, naczyń, sztućców, zdrowej wody.

Poseł Sabath cytuje fragment raportu komisarza Watchorna dotyczącego pracy stacji w 1907 roku.

W roku, który wtaśnie się zakończyt, stacja przyjęta 1506 dzieci zarażonych odra, dyfterytem i szkarlatyna $i$ wszystkie te choroby $z$ większym lub mniejszym stopniu zostały wywołane nadmiernym zatłoczeniem i złymi warunkami higienicznymi. Z tej liczby 205 dzieci umarło.

Imigranci lądujący na Ellis Island dodają swoje. Skarżą się, że lekarze omijają steerage, że kto słabiej pcha się do kotła, odchodzi głodny, że z dziur w suficie stanowiącym podłogę górnego deku sypią się brudy, że bagaże wepchnięte pod prycze, bo nie ma szaf ani półek, jeżdżą po pokładzie przy każdym przechyle statku, że koce są zawszone, umywalnie czynne tylko 
w określonych porach dnia, a niektórzy pasażerowie nie umieją sobie radzić z potrzebami i załatwiają się w kątach.

Podróżni, którzy wnoszą protesty, słyszą od załogi, że kto chce podróżować jak człowiek, powinien wykupić sobie kabinę, bo steerage nie jest miejscem dla istot ludzkich, ale dla bydła ${ }^{35}$.

Temat lekcji: Trudna droga do kraju wolności — refleksje wokół reportażu Małgorzaty Szejnert pt. Wyspa klucz

Przebieg lekcji

\section{Ogniwo wstępne (10 min)}

Nauczyciel zapisuje na tablicy słowo „WOLNOŚĆ”, po czym pyta uczniów, co oznacza dla nich to pojęcie. Uczniowie dzielą się na forum klasy swoimi przekonaniami, skojarzeniami (np.: niezależność, możliwość podejmowania samodzielnie decyzji, prawo do wypowiadania się na dany temat, niepodleganie karze pozbawienia wolności itp.). Następnie prowadzący pokazuje uczniom fotografię przedstawiającą Statuę Wolności i zadaje pytania: czy znają ten pomnik? Z czym się on kojarzy oraz dlaczego ich zdaniem Stany Zjednoczone Ameryki Północnej są dla obywateli innych państw synonimem wolności i dobrobytu? Uczniowie wygłaszają swoje poglądy na ten temat.

2. Ogniwo centralne (30 min)

Nauczyciel rozdaje uczniom fragment reportażu Wyspa klucz (załącznik nr 1) oraz krótko charakteryzuje, że dotyczy on procedury praktykowanej na Ellis Island - centrum przyjmowania imigrantów do USA, które działało w latach 1892-1954.

Po przeczytaniu tekstu prowadzący dzieli klasę na dwie grupy, z których jedna ma wczuć się w rolę imigranta, a druga - lekarza inspekcyjnego. Nauczyciel zadaje pytania pomocnicze: dlaczego Amerykanie mogli bać się przybyszów z innych kontynentów? Czy chorzy, niepełnosprawni imigranci stanowią realne zagrożenie dla docelowego kraju? Czy władze państw mają prawo do decydowania o losie jednostki na podstawie jej stanu zdrowia, sytuacji życiowej itp.? Czy tego typu działania są ingerencją w prawo człowieka do wolności? Rozwija się dyskusja, w której grupy mają wzajemnie się przekonać, co do słuszności lub jej braku w przyjmowaniu w taki sposób imigrantów do Stanów Zjednoczonych. Jednocześnie podczas interpretacji fragmentu nasuwa się skojarzenie opisanej segregacji, w której uwydatnione jest uprzedmiotowione podejście do

\footnotetext{
${ }^{35}$ Ibidem, s. $85-90$.
} 
drugiego człowieka, z działaniami nazistów w czasach drugiej wojny światowej (obozy koncentracyjne).

Następnie nauczyciel rozdaje klasie kolejny fragment (załącznik nr 2), tym razem dotyczący podróży imigrantów do USA. Uczniowie mają zastanowić się, czy opisane warunki podróży są, ich zdaniem, naruszeniem praw przynależnych człowiekowi (po raz kolejny można tu odnaleźć analogie do drugiej wojny światowej - transporty do obozów). Prowadzący pyta klasę, czy sytuację osób emigrujących do Stanów Zjednoczonych na początku XX wieku można porównać do współczesnego statusu uchodźców z krajów arabskich i afrykańskich. Prosi o wyjaśnienie różnicy między imigrantem a uchodźcą, pyta, czy zdaniem uczniów ta kwestia ma znaczenie. Jak klasa odbiera tę analogię wobec faktu, że w opisywanych fragmentach „obcy” to m.in. również Polacy? Nauczyciel prosi o wskazanie przyczyn strachu przed innym, nieznanym — dawniej i dziś. Nawiązuje się rozmowa: czy kraje europejskie powinny przyjmować imigrantów i uchodźców? Czy jest to szansą czy zagrożeniem? Uczniowie w małych grupach zapisują swoje refleksje w postaci mapy mentalnej.

3. Ogniwo końcowe (5 min)

Nauczyciel podsumowuje informacje zebrane na lekcji - niewątpliwie temat imigrantów i uchodźców jest kwestią niejednoznaczną i trudną. Władze państw muszą dbać o dobro i bezpieczeństwo swoich obywateli i, jak widać, od setek lat problematyczne jest rozwiązanie tej kwestii z satysfakcją dla obu stron. Należy mieć jednak na uwadze dążenie do jak najsprawiedliwszego i najgodniejszego traktowania przybyszów z innych krajów z poszanowaniem ich praw.

\section{Bibliografia}

Adamczuk-Stemplewska A.: Wielokulturowość w polskiej literaturze najnowszej jako przedmiot kształcenia polonistycznego na etapie liceum. W: Wyczytać świat - międzykulturowość w literaturze dla dzieci i młodzieży. Red. B. Niesporek-Szamburska, M. Wójcik-Dudek. Katowice 2014.

Bauer W.: Przez morze. Z Syryjczykami do Europy. Tłum. E. Kalinow ska. Wołowiec 2016.

Cekiera R.: Terroryści, tchórze i lenie — konstruowanie wizerunku uchodźców za pomoca memów internetowych. „Kultura. Media. Teologia” 2017, nr 29.

Demick B.: Światu nie mamy czego zazdrościć. Zwyczajne losy mieszkańców Korei Pótnocnej.

Tłum. A. Nowakowska. Wołowiec 2011.

Domosławski A.: Wykluczeni. Warszawa 2016.

Fudge J.: Granice - w tym samym mieście, pod tym samym niebem. W: W tym samym mieście, pod tym samym niebem... Red. A. Konik. Warszawa 2016.

Homer: Odyseja. Tłum. L. Siemieński. Warszawa 1990. 
Janus-Sitarz A.: Arcydzieła niepoprawne, czyli o potrzebie krytycznego czytania. W: W trosce o dobra edukację. Teksty dedykowane profesor Jadwidze Kowalikowej. Red. A. Janus-Sitarz, M. Madejowa. Kraków 2009.

Kapuściński R.: Lapidaria I-III. Warszawa 2008.

Kingsley P.: Nowa Odyseja. Opowieść o kryzysie uchodźczym w Europie. Tłum. A. Paszkowska. Warszawa 2017.

Koc K.: Czytanie świata. Reportaże Ryszarda Kapuścińskiego w edukacji polonistycznej. Poznań 2007.

Koc K.: Szkolna narracja o uchodźcach a formacyjny wymiar edukacji polonistycznej. „Polonistyka. Innowacje" 2017, nr 6.

Koziołek K.: Czas lektury. Katowice 2017.

Markowski M.P.: Polityka wrażliwości. Wprowadzenie do humanistyki. Kraków 2013.

Mazuś M.: Król kebabów i inne zderzenia polsko-obce. Warszawa 2015.

Mikołajewski J.: Wielki przypływ. Warszawa 2015.

Nussbaum M.C.: Czytać, aby żyć. „Teksty Drugie” 2002, nr 1/2.

Ochwat M.: (Od)pamiętywanie, czyli o powinnościach dydaktycznych wobec wielokulturowości na przykładzie książki Marcina Kąckiego „Białystok. Biała siła, czarna pamięć”. W: (Od)pamiętywanie - gry z przeszłościa w literaturze dla dzieci i młodzieży. Red. B. Niesporek-Szamburska, M. Wójcik-Dudek. Katowice 2018.

Ochwat M.: O uchodźcach z Grecji (i nie tylko) na lekcji we współczesnej szkole - Nowe życie. Jak Polacy pomogli uchodźcom z Grecji Dionisiosa Sturis. „Postscriptum Polonistyczne” 2018, nr 2.

Ochwat M.: O społecznej odpowiedzialności edukacji polonistycznej i (nowych) lekturach na rzecz wychowania do pokoju. „Czas Kultury” 2018, nr 3.

Prymaka-Oniszk A.: Bieżeństwo 1915. Zapomniani uchodźcy. Wołowiec 2016.

Sturis D.: Nowe życie. Jak Polacy pomogli uchodźcom z Grecji. Warszawa 2016.

Szejnert M.: Wyspa klucz. Kraków 2009.

Szopiński M.: Jak czytaliśmy teksty o uchodźcach Jarosława Mikołajewskiego? Refleksje nauczyciela po lekcji akademickiej. „Polonistyka. Innowacje” 2017, nr 6.

Tochman W., Boni K.: Kontener. Warszawa 2014.

Tubylewicz K.: Moraliści. Jak Szwedzi ucza się na błędach i inne historie. Warszawa 2017.

Wiszniowska M.: Zobaczyć — opisać — zrozumieć. Polskie reportaże literackie o rosyjskim imperium. Katowice 2017.

Wolny-Zmorzyński K.: Reportaż jak go napisać? Poradnik dla stuchaczy studiów dziennikarskich. Warszawa 2004.

Zimnoch M.: Reportaż w ptynnej nowoczesności. „Znak” 2012, nr 682.

\section{Źródła internetowe}

http://audycje.tokfm.pl/podcast/Polska-szkola-reportazu-polska-szkola-zmyslania-Dyskutuja-

-Mariusz-Szczygiel-Adam-Leszczynski-i-Tomasz-Stawiszynski/50160.

http://culture.pl/pl/artykul/polskie-non-fiction-w-tlumaczeniu-i-nie.

http://culture.pl/pl/artykul/polskie-non-fiction-w-tlumaczeniu-i-nie\#rank.

http://culture.pl/pl/artykul/wojciech-tochman-o-polskim-reportazu-wywiad.

http://instytutr.pl/pl/polska-szkola-reportazu/.

http://katowice.wyborcza.pl/katowice/1,35055,19784678,ryszard-koziolek-houellebecq-ukradl-

-mysl-z-mojej-glowy.html. 
http://krytykapolityczna.pl/kultura/czytaj-dalej/leszczynski-polska-szkola-zmyslania/.

http://www.focus.pl/artykul/czy-polakom-brakuje-empatii-wyniki-tych-bada-nie-s-najlepsze.

http://www.press.pl/magazyn-press/artykul/36084,polskie-non-fiction-za-granica.

http://www.radiomaryja.pl/kosciol/homilia-ojca-swietego-franciszka-wygloszona-na-wyspie-

-lampedusa/.

http://www.wysokieobcasy.pl/wysokie-obcasy/7,115167,20918341,najwieksze-swiatowe-badanie-

-empatii-co-z-niego-wynika.html.

https://men.gov.pl/wp-content/uploads/2018/01/zalacznik-nr-1.pdf.

https://www.facebook.com/instytutreportazu/. 